\title{
Nutrient dynamics of corn fed to livestock in conservation-based agroecosystems in neotropical savannas
}

\author{
Dinâmica de nutrientes em milho para alimentação de gado em agroecossistemas baseados na \\ conservação de savanas neotropicais
}

\author{
Elizabeth Ramírez-Iglesias ${ }^{1 \star}$, Rosa Mary Hernández-Hernandez ${ }^{2}$, José Rubén Iglesias ${ }^{3}$ \\ ${ }^{1}$ Universidad Estatal Amazónica, El Pangui-Zamora Chinchipe, Ecuador. * Author for correspondence: ec.ramirez@itme.org \\ ${ }^{2}$ Universidad Nacional Experimental Simón Rodriguez, Caracas, Venezuela. \\ ${ }^{3}$ Universidad internacional SEK, Quito, Ecuador.
}

Submission: 27/09/2020 / Acceptance: 14/12/2020

\begin{abstract}
Mineral deficiencies in soil-plant-animal relations are linked to chemical properties and reproductive problems in grazing animals. The objective of this study was to determine the dynamics of $\mathrm{K}, \mathrm{Ca}$, and $\mathrm{Mg}$ in the green leaf biomass of two types of introduced forages, Brachiaria dyctioneura (Bd) and Centrosema macrocarpum $(\mathrm{Cm})$, compared to the natural vegetation of the neotropical savannah (NS) in an agricultural ecosystem. The three types of vegetation, associated with the corn crop, served as livestock feed during the dry season. The soil's nutrient content $(0-15 \mathrm{~cm}$ depth), the production and nutritional dynamics of green leaf biomass, and leaf/stem relationships in the fields during the grazing period were determined. In the corn crop-livestock agroecosystem, $\mathrm{K}$ decreased (\%) in concentration as the grazing period progressed, presenting the following trend: $\mathrm{Bd}>\mathrm{Cm}>\mathrm{NS}$. The dynamics of $\mathrm{Ca}$ and $\mathrm{Mg}$ in green leaf biomass increased slightly $(p<0.05)$ by the end of the grazing period for $\mathrm{Bd}$ and $\mathrm{Cm}$, in contrast to a significant decrease in the natural vegetation of the savannah. The concentration of $\mathrm{K}$ in the soil did not reveal significant differences between ground cover and NS plants, and the soils under Cm evidenced the highest percentage of $\mathrm{Ca}$. A higher percentage of $\mathrm{Mg}$ was observed in the soil planted with $\mathrm{Cm}$. For the three types of vegetation, an improvement was observed in the nutritional quality of the forage and soil and in the yield $(\mathrm{kg} / \mathrm{ha})$. These findings are valuable contributions within the context of production in savannas and to forage quality for livestock.
\end{abstract}

KEYWORDS: minerals, soil-plant relations, cover crops.

\section{RESUMO}

Deficiências minerais no eixo solo-planta-animal estão relacionadas as propriedades químicas e estão ligadas a problemas reprodutivos em animais em pastejo. $O$ objetivo deste estudo foi determinar a dinâmica de $\mathrm{K}, \mathrm{Ca}$ e $\mathrm{Mg}$ na biomassa foliar verde de dois tipos de forrageiras introduzidas (Brachiaria dyctioneura $(\mathrm{Bd})$ e Centrosema macrocarpum $(\mathrm{Cm})$ ) em relação à vegetação natural do cerrado (NS) em um ecossistema agrícola. Os três tipos de vegetação, associados ao cultivo do milho, serviam de ração para o gado durante a estação seca. Foram determinados o conteúdo de nutrientes no solo $(0-15 \mathrm{~cm}$ de profundidade), a produção de biomassa de folhas verdes e sua dinâmica nutricional e as relações folhacolmo nas lavouras durante o pastejo. No agroecossistema milho-pecuária, o $\mathrm{K}$ apresentou redução (\%) em sua concentração com o avanço do período de pastejo, apresentando a seguinte tendência: $\mathrm{Bd}>\mathrm{Cm}>$ NS. A dinâmica do $\mathrm{Ca}$ e $\mathrm{Mg}$ na biomassa foliar verde aumentou ligeiramente $(p<0,05)$ ao final do período de pastejo em $\mathrm{Bd}$ e $\mathrm{Cm}$, contrastando com uma diminuição significativa na vegetação natural do cerrado. A concentração de $\mathrm{K}$ no solo não apresentou diferenças significativas entre as plantas de cobertura e 0 NS, sendo que os solos sob $\mathrm{Cm}$ apresentaram a maior porcentagem de $\mathrm{Ca}$. Uma maior porcentagem de $\mathrm{Mg}$ foi observada no solo plantado com $\mathrm{Cm}$. Nos três tipos de vegetação examinados, observou-se melhora na qualidade nutricional da forragem e solo e na produtividade $(\mathrm{kg} / \mathrm{ha})$. Essas descobertas são contribuições valiosas nos contextos de produção das savanas e na qualidade da forragem para o gado.

PALAVRAS-CHAVE: minerais, relações solo-planta, culturas de cobertura.

\section{INTRODUCTION}

The lack or excess of minerals in soil-plant-animal relations are caused by complex interactions in the 
soil, resulting in either low growth rates for forages due to the scarcity of minerals or toxicity due to their excessive concentrations, and thus have an antagonistic effect on the absorption of other elements by plants. With harvesting, large amounts of nutrients are extracted, which can spur an imbalance in the soil and its rapid impoverishment and lead to a decrease in yield and to poor-quality forage crops. The crop's nutrient uptake is strongly influenced by factors such as climate, genotype, cropping systems, and productivity levels. Therefore, in addition to increasing the amounts of nutrients in the fertilization of cornbased forage, it is essential to implement crop rotation and to avoid silage production for consecutive years in one area. Introducing perennial plants for ground cover also reduces the soil's susceptibility to erosion (RAMÍREZ-IGLESIAS et al. 2020).

In cereal crop-livestock production systems, whose purpose is to optimize crop yields per hectare and provide feed for grazing, the extraction of nutrients occurs systematically (HOLLAND et al. 2019, JOHNSON et al. 2019) and affects not only soil fertility, but also physical conditions, due to their role in aggregate stability and in air and water dynamics (SHAIN et al. 2005, HERNÁNDEZ et al. 2011, LIMA \& BASTOS 2019).

LOZANO et al. (2012) note that the introduction of perennial ground cover plants such as Brachiaria dyctioneura $(\mathrm{Bd})$ and Centrosema macrocarpum $(\mathrm{Cm})$ induces an improvement in the $\mathrm{pH}$ of savanna soils and an increase in organic matter (OM) in the top layers of the soil. The introduction of these forages tends to favor the soil's top layers and increased concentrations of $\mathrm{K}, \mathrm{Ca}$, and $\mathrm{Mg}$ (RAMÍREZ-IGLESIAS et al. 2017a, PHILP et al. 2019). Authors such as AGUIRRE et al. (2019) and ALEJANDRO-MARTíNEZ et al. (2019) maintain that the availability of these three elements in the soil, in addition to their interchangeable phases, is determined mainly by the cation-exchange capacity, based on the competition among these elements in the soil exchange complex, or by the active absorption sites of plant roots.

Specifically, K helps regulate the osmotic potential of plant cells, especially in enzymes directly related to respiration and photosynthesis (SRIVASTAVA et al. 2020). Calcium, on the other hand, is an essential nutrient for the plant since it involves cell elongation processes (BOLÍVAR et al. 2009) and favors cell wall formation (SLANAC et al. 2019), while Mg is the central element of chlorophyll, which is responsible for carrying out the process of photosynthesis (HIDALGO-SUÁREZ et al. 2019).

The objective of this study was to establish important aspects about the extraction and export of soil nutrients by corn used as forage. For an integral understanding of the agroecosystem and soil-plant relationships, the dynamics of $\mathrm{K}, \mathrm{Ca}$, and $\mathrm{Mg}$ in the green leaf biomass and in the soil at a depth of $0-15 \mathrm{~cm}$ for the two types of introduced forages, $\mathrm{Bd}$ and $\mathrm{Cm}$, were explored in comparison with NS plants as the control. It is important to note that the three types of vegetation are associated with the corn crop and served as livestock feed in the dry season; thus, a comprehensive study of soil-plant relationships will provide a holistic view of the agroecosystem for more robust productivity management.

\section{MATERIAL AND METHODS}

\section{Description of the experimental area}

The experiment was conducted in well-drained savanna ecosystems located in the Central-Eastern plains of the Venezuelan Llanos, within the northern zone of influence of the Orinoco River, at the La Iguana Experimental Station ( $\left.8^{\circ} 25^{\prime} \mathrm{N}, 65^{\circ} 25^{\prime} \mathrm{W}\right), 80-120$ meters above sea level (RIERA \& GUERRERO 1984). The area presents bi-seasonal climate patterns which include a dry period from November to May and a rainy period from June to October. Total annual precipitation ranges from 950 to $1300 \mathrm{~mm}$, while monthly average temperatures range between $26^{\circ} \mathrm{C}$ and $30{ }^{\circ} \mathrm{C}$ (RAMÍREZ-IGLESIAS et al. 2020).

\section{Experimental design}

The design involved three paddocks that were each $15 \mathrm{~m} \times 200 \mathrm{~m}$ in size, one paddock for each of the ground cover plants $\mathrm{Bd}$ and $\mathrm{Cm}$ and one for the control NS vegetation. They were each exposed to an animal load of 1.04 AU.ha $^{-1}$ for 110 days. All of the paddocks also contained an indefinite amount of corn mulch.

We worked with a total of 36 weaned mixed-breed Criollo Limonero calves with a predominance of the Zebu breed, which meant 16 calves $(n=16)$ for each introduced ground cover plant and 4 calves $(n=4)$ in the control paddock (NS). Two weeks prior to introducing the calves into the paddocks, the animals were vaccinated and dewormed and underwent a period of adaptation to the available forages and to the electric fences placed in the trial paddocks as barriers between the separate treatments (RODAS-GONZÁLEZ et al. 2006, RAMÍREZ-IGLESIAS et al. 2020).

To quantify the total aerial biomass of the forage, a ring with a diameter of $50 \mathrm{~cm}$ was used, inside of which all plant material was cut to the surface of the ground. The ring was thrown at random a total of 
6 times: 0, 40, 60, 80, and 110 Days After the Animals were Introduced (DAIA) to each paddock. The plant material was separated into green leaves and stems that were dried at $40{ }^{\circ} \mathrm{C}$ for 72 hours and weighed (AOAC 1980, BROWN 1997). Each plant biomass sample was ground in a Wiley mill for a subsequent analysis of the dynamics of $\mathrm{K}, \mathrm{Ca}$, and $\mathrm{Mg}$. Soil samples (1-15 cm depth) were extracted from the same locations as the plant samples and also examined for concentrations of $\mathrm{K}, \mathrm{Ca}$, and $\mathrm{Mg}$.

\section{Statistical analysis}

Descriptive analyses of data and analyses of variance (ANOVA) were used to observe responses to the effects of $\mathrm{Bd}$ and $\mathrm{Cm}$ and compare them with the responses to NS. Pearson correlations and linear regressions were utilized for this experimental model. DUNCAN's test (1974) was used for comparisons as it demonstrated to be the most powerful test for this design, with a significance level of $p<0.05$.

\section{RESULTS AND DISCUSSION}

\section{Dynamics of green leaf biomass production and leaf/stem relationships during the grazing cycle in a corn crop-livestock agroecosystem.}

Forage production in terms of green leaf biomass (GLB), dry matter ( $\mathrm{kgDM} / \mathrm{ha})$, and leaf/stem ratio (L:S) are shown in Figure 1.
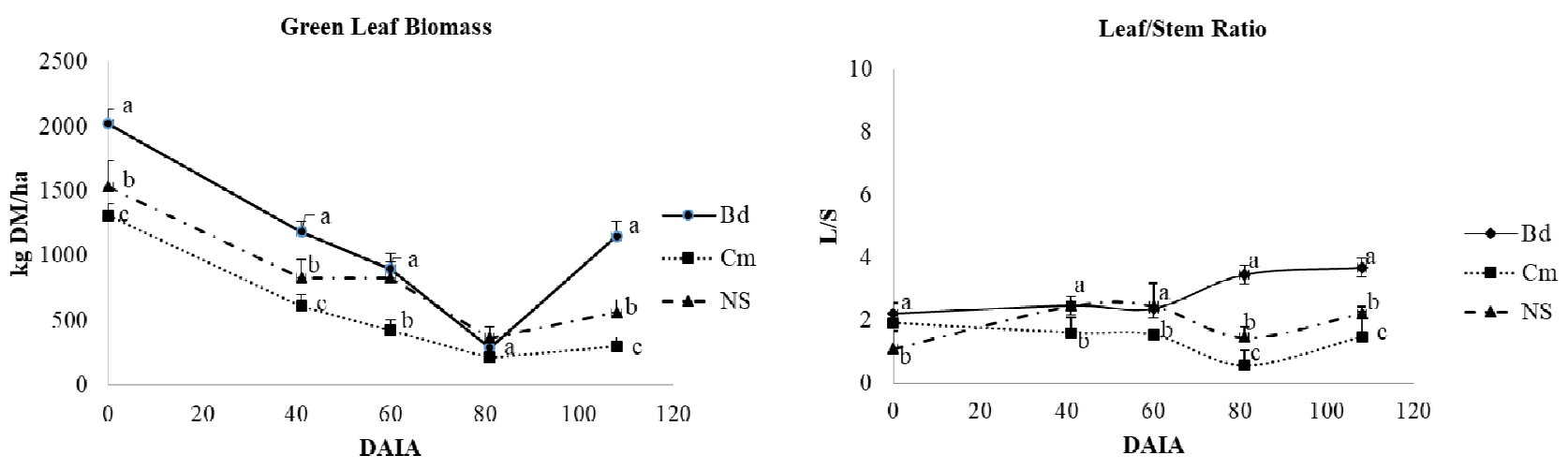

Figure 1. Production of green leaf biomass $(\mathrm{kgDM} / \mathrm{ha})$ and leaf/stem ratio during the grazing cycle in a corn crop-livestock agroecosystem. Different letters indicate significant differences between treatments (DUNCAN p<0.05). Brachiaria dyctioneura $(\mathrm{Bd})$, Centrosema macrocarpum $(\mathrm{Cm})$, and natural savanna (NS). Bars indicate standard deviation.

GLB production was higher in the beginning of the grazing period for $\mathrm{Bd}$ with $2020.74 \mathrm{kgDM} / \mathrm{ha}$, followed by NS with 1530.47 , and finally $\mathrm{Cm}$ with $1275.95 \mathrm{kgDM} / \mathrm{ha}$. As the grazing period progressed, a general declining trend in biomass production was detected as a result of intensive grazing. Statistically significant differences were observed between Bd-NS and $\mathrm{Cm}(\mathrm{p}<0.05) 40$ and 60 DAIA. It is important to note that grasses had greater biomass than legumes, which may be due to the fact that a greater amount of moisture was retained by the mulch in soils planted with Bd. This allowed GLB to be higher for grasses and NS vegetation, unlike the $\mathrm{Cm}$ plants, which were consumed by cattle more often, in addition to the direct impact on the soil from trampling. The lowest production of dry matter (DM) production was observed 80 DAIA, and then there was a rebound towards the initial levels of productivity, possibly because of a species rebound after defoliation. On the other hand, the biomass recovery of Bd plants is possibly related to the livestock's selectivity and palatability, demonstrating a preference for the legume (C3 plants), as the growth of $\mathrm{Bd}$ (C4 plants) exhibited greater lignification. It was also less palatable for livestock, so it presented less defoliation and greater recovery.

VIERA et al. (2019) argue that the species and their vegetation composition can have a considerable effect on the accumulation of organic matter (OM) in the soil, favoring decomposition via microbial communities, while this activity is limited in the dry season. RAMÍREZ-IGLESIAS et al. (2017a) claim that increased production of GLB can mean an alternative for livestock in the dry season. Despite intensive grazing in pastures, there is still a quantity of green plant material after that process that can be consumed by livestock.

The L/S ratios at the beginning of the cycle did not reveal significant differences between the introduced plants, in contrast to the NS plants. As grazing continued, the dynamics of the relationship between leaf and stem favored a greater quantity of leaves in the case of grasses, unlike the legume $(\mathrm{Cm})$, 
whose dynamics during the cycle demonstrated lower ratios, as this legume presented a greater number of expressively distinct stems.

\section{Dynamics of $\mathrm{K}, \mathrm{Ca}$, and $\mathrm{Mg}$ in green leaf biomass during grazing}

The results for the dynamics of $\mathrm{K}, \mathrm{Ca}$, and $\mathrm{Mg}$ in green leaf biomass during grazing are shown in Figure 2. At the beginning of the grazing period, $\mathrm{K}$ concentrations in the green leaves of $\mathrm{Cm}$ and NS plants were similar, while they were significantly lower for Bd (Figure 2). Among the agroecosystems, the maximum $\mathrm{K}$ concentration in GLB quickly peaked in Bd plants 40 DAIA (1.90\%), and then $\mathrm{K}$ concentration declined until the end of the grazing period. Similar behavior was observed in legumes $(\mathrm{Cm}) 80$ DAIA, which registered a second peak but at a lower range. The values for NS plants suffered a gradual decrease throughout the whole grazing period, with a slight increase 80 DAIA. In the control treatment, $\mathrm{K}$ levels were always significantly below those presented by the introduced ground cover plants.

Similar findings for NS plants are reported by CHACÓN et al. (2007) and RAMÍREZ-IGLESIAS et al. (2017b), who note that the critical value of $\mathrm{K}$ for forages is $0.7 \%$, thus highlighting that native grasses usually present deficiencies of this nutrient and do not reach the minimum values required for cattle feeding. In production systems, it is important to maintain K above critical levels (JOHNSON et al. 2019), since one of the functions of this element is to intervene in the processes of photosynthesis and protein synthesis, which improves the plant's resistance to periods of drought (HOLLAND et al. 2019) and could be an important factor in corn crop-livestock agroecosystems in savannas, where water stress limits productivity.
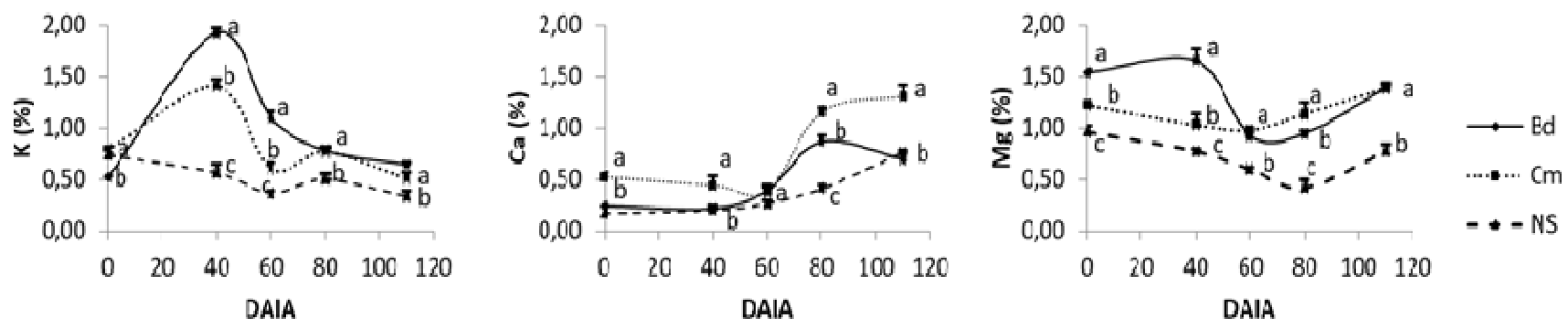

Figure 2. Dynamics of $\mathrm{K}, \mathrm{Ca}$, and $\mathrm{Mg}$ in the green leaf biomass (GLB) of ground cover plants during grazing $\mathrm{Bd}$ : Brachiaria dyctioneura; $\mathrm{Cm}$ : Centrosema macrocarpum; NS: natural savanna. Different letters indicate statistically significant differences for each sampling time between ground cover plants. DAIA: days after introduction of animals (DUNCAN $p<0.05, n=48$ ).

The highest $\mathrm{Ca}$ content was found in legumes $(\mathrm{Cm})$, except on the 60th DAIA, where no significant differences were observed between the introduced ground cover plants and NS plants. For all ground cover plants, the pattern was similar: low, stable values in the first two months of grazing, followed by an increase toward the 80th DAIA, which stabilized in the introduced ground cover plants associated with the corn crop, followed by another increase after four months of continuous grazing. By the end of this period, there were no significant differences between Bd and NS. The values obtained for $\mathrm{Ca}$ in GLB were similar to those reported by SÁNCHEZ \& MORENO (1994) and HERNÁNDEZ et al. (2011), who indicate a value of $0.22 \%$ for $\mathrm{Ca}$ in Bd plants under grazing conditions. GODOY et al. (2007) present critical values around $0.25 \%$ for $\mathrm{Ca}$ in forage species growing in the Venezuelan plains. Because this element forms part of the cell membrane structure of plants, translocation is unlikely to occur, which means that it is hardly affected by the plant's vegetative phases or by the time of year (SLANAC et al. 2019, PHILP et al. 2019).

At the beginning of the cycle, the grass presented higher concentrations of $\mathrm{Mg}$, followed by the legume and the natural vegetation of the savanna. This pattern was maintained in the first two months of grazing, when $\mathrm{Mg}$ decreased significantly $(p<0.05)$, and Bd's levels were equal to those found in the GLB of the legume. However, the increase in the GLB of NS plants (80 DAIA) occurred some time after it had increased in the other ground cover plants, which means that by the end of the grazing period, the GLB of the Bd and $\mathrm{Cm}$ plants had more $\mathrm{Mg}$ than the GLB of the NS plants $(\mathrm{p}<0.05)$. In the literature, the critical values for $\mathrm{Mg}$ are around $0.20 \%$ (MOSQUERA \& LASCANO 1992, CHACÓN et al. 2007). In this study, the average Mg values in the corn crop-livestock agroecosystem were above the indicated level, $0.77 \%$ for the $\mathrm{GLB}$ of $\mathrm{Cm}$ plants, $0.49 \%$ for $\mathrm{Bd}$, and $0.37 \%$ for NS. Thus, it can be stated that the introduction of perennial coverages improved the status of $\mathrm{K}, \mathrm{Ca}$, and $\mathrm{Mg}$ levels in the fraction of the plant subject to the cattle's selectivity, such as GLB. For almost all of the time periods evaluated, the concentrations of these elements in the introduced ground cover plants were higher than those of the NS vegetation, thus improving the critical values reported 
in the literature, even for native vegetation alone. On the other hand, it is important to emphasize that defoliation due to intensive grazing, a product of the pasture management design, generated a decrease in green plant biomass. Although the concentrations of $\mathrm{Ca}$ and $\mathrm{Mg}$ in leaf tissues increased at the end of the cycle, their contribution to the agroecosystem in terms of $\mathrm{kg} / \mathrm{ha}$ decreased over time.

Dynamics of $\mathrm{K}, \mathrm{Ca}$, and $\mathrm{Mg}$ in the soil of the corn crop-livestock agroecosystem during grazing

The results obtained in relation to the $\mathrm{K}$ content in the soil at the sampled depth $(0-15 \mathrm{~cm})$ show significant differences between treatments $(p<0.05)$, favoring NS plants, in contrast to the introduced ground cover plants. As the grazing season continued, lower nutritional contents of this element were observed in the soil. By establishing correlations with the GLB and the soil at a depth of 0-15 cm 40 DAIA, a significant correlation for $\mathrm{Bd}(r=0.56)$ was obtained $(p<0.05)$. Significant correlations were observed for the introduced ground cover plants 80 and 110 DAIA: Bd presented a value of $r=0.60$, while it was $r=0.52$ for legumes, and it showed no significance for NS. As the grazing season progressed, the concentrations of this cation in the soil solution favored mainly the grass, followed by $\mathrm{Cm}$ and then NS (Figure 3).
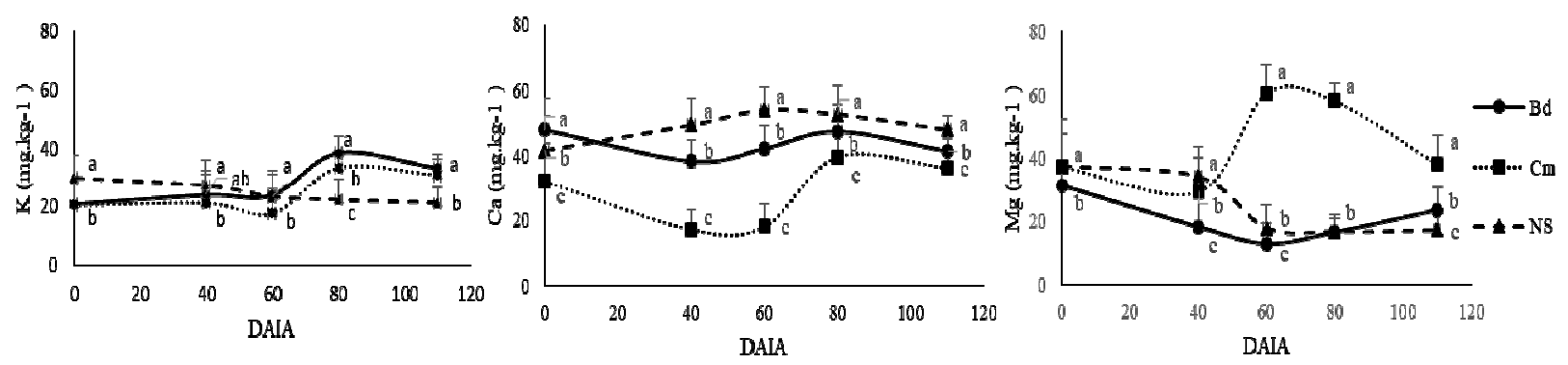

Figure 3. Dynamics of $\mathrm{K}, \mathrm{Ca}$, and $\mathrm{Mg}$ in the soil at a depth of $0-15 \mathrm{~cm}$ during grazing $\mathrm{Bd}$ : Brachiaria dyctioneura; Cm: Centrosema macrocarpum; NS: natural savanna. Different letters indicate statistically significant differences for each sampling time between ground cover plants. DAIA: days after introduction of animals (DUNCAN $p<0.05$ ).

As for $\mathrm{Ca}$, higher initial concentrations were observed for NS, followed by $\mathrm{Bd}$ and then $\mathrm{Cm}$, thus revealing significant correlations between the soil and GLB in NS ( $r=0.45), B d(r=0.56)$, and $C m(r=0.54)$, which maintained the same trend until 40 DAIA. The trend was maintained until $60 \mathrm{DAIA}$, but the differences were more apparent at that time of grazing, demonstrating greater correlations between soil-plant components. The value for NS was $r=0.54$, followed $r=0.62$ for $B d$ and $r=0.55$ for the legume. However, at the end of the grazing period, no significant differences were observed in the Ca content of the soil in the comparison between the three types of ground cover plants. According to RODRíGUEZ et al. (2004) and LÓPEZ et al. (2008), there are evident Ca deficiencies in the acidic soils of the central and eastern savannas of Venezuela, where extensive areas dedicated to livestock are found. On the other hand, DEPABLOS et al. (2009) found that $40 \%$ of the livestock production units in savannas of the state of Cojedes in Venezuela presented soils with $\mathrm{Ca}$ deficiencies, which is a general characteristic of this type of agroecosystem. Other studies, such as BORGES et al. (2012), found low levels of $\mathrm{Ca}$ in the sampled agricultural soils, with values below $500 \mathrm{mg} \mathrm{kg}^{-1}$. Levels of $\mathrm{pH}$ showed a strong association with the availability of nutrients, especially calcium ( $r=0.79$ ), which was lacking in acid soils. These corresponded to $58.6 \%$ of the sampled pastures, thereby demonstrating that acidity and relief affect the availability of nutrients such as $\mathrm{P}$ and $\mathrm{Ca}$. This is consistent with the results obtained in the soils of this study. For the natural savanna and introduced ground cover plants, Ca presented low values when contrasted with the reference values. Several studies indicate that $\mathrm{Ca}$ is required in the animal for normal blood coagulation, and it maintains neuromuscular excitability and enzyme activity. It is known as a multifunctional element. In that sense, the dynamics observed herein reveal that there was a higher concentration of this element both in the soils of the grass (Bd) and of NS vegetation, unlike the leguminous $(\mathrm{Cm})$, which exhibited lower concentrations of $\mathrm{Ca}$ as the highest proportions of this element were found in the biomass of the ground cover plant.

The $\mathrm{Mg}$ content in the soil decreased for all three types of vegetation from the beginning to 40 DAIA, exhibiting similar behavior to that of GLB, except in the case of the NS plants, wherein the Mg concentration in GLB increased. Following the $60^{\text {th }}$ DAIA, the concentrations of this cation tended to increase in the soil solution in the case of the NS plants and legumes; however, the downward trend continued for Bd. Concentrations of $\mathrm{Mg}$ in legumes $(\mathrm{Cm})$ tended to increase again 80 DAIA, while their concentrations in GLB decreased, presenting a significant correlation of $r=0.52$. In the natural savanna vegetation and grass, the 
concentration of this cation decreased in the green leaf biomass and in the soil, thereby exhibiting similar characteristics.

The use of direct sowing possibly provided the soil surface with a higher content of nutrients, which was higher in the case of $\mathrm{Bd}$ plants for $\mathrm{K}$ and $\mathrm{Mg}$, in contrast to the $\mathrm{Cm}$ and NS plants, exhibiting a similar pattern of behavior in concentration levels in the green leaf biomass, which is possibly related to the availability of $\mathrm{Mg}$ in the soil solution and in its fixation by the plant in its leaf biomass.

The mineral content of forages can be affected by various factors such as forage species, phenological stage, climate and seasonal conditions, soil type, fertilization, and the presence of antagonistic elements (RAJKUMAR et al. 2012, BALAREZO et al. 2017, RAMÍREZ-IGLESIAS et al. 2020). Their biological availability depends on the mineral source and interactions between the different elements that make up the animal's diet, which can limit their absorption and predispose them to imbalances, although the soil and forage content are appropriate (McDOWELL \& ARTHINGTON 2005).

On the other hand, it has been noted that the availability of trace minerals can be affected by the microbiological activity present in the rhizosphere (RAJKUMAR et al. 2012). However, there is no conclusive information on these processes, but some research indicates that plants and associated microorganisms can exude compounds that improve or reduce the mobility of micronutrients (DONNER et al. 2012).

The higher concentrations of nutrients in the most superficial layer of the soil in these agroecosystems are possible due to the presence of residues on the surface in the form of mulch, which remained on the surface in the absence of tillage. Another possibility is that the nutrients extracted by the plant from the deepest layers are deposited on the surface by the nutrient cycling of residues, as mentioned by various authors (JOHNSON et al. 2019, ALEJANDRO-MARTíNEZ et al. 2019).

\section{CONCLUSION}

Understanding the dynamics of biomass production and the leaf-stem and nutritional relationships between the soil and plant components in corn, grass, and legumes allows for a holistic approach in the management of savanna agroecosystems. The introduction of $\mathrm{Bd}$ and $\mathrm{Cm}$ rendered a greater nutritional contribution to forages than NS plants, thus favoring nutrient cycles, the formation of mulch, soil fertility, and the forage supply for livestock during the dry season in neotropical savannas.

\section{REFERENCES}

AGUIRRE SE et al. 2019. Valoración del estado del suelo en Zona de Bosque Seco Tropical mediante técnicas analíticas y cromatogramas. Información tecnológica 30: 337-350.

ALEJANDRO-MARTíNEZ PD et al. 2019. Efecto del cambio de uso de suelo sobre las propiedades edáficas en La Sabana, Huimanguillo, Tabasco-México. AGRO Productividad 12: 95-100.

AOAC. 1980. Methods of analysis. 13.ed. Washington D.C: Association of official analysis chemistry. 125-187p.

BALAREZO LR et al. 2017. Contenido mineral en suelo y pastos en rebaños bovinos lecheros de la región andina de Ecuador. Centro Agrícola 44: 56-64.

BOLÍVAR MIV et al. 2009. Efecto de las deficiencias de algunos nutrientes en plantas de lulo (Solanum quitoense var. quitoense) en etapa de vivero. Revista Facultad de Ciencias Básicas 5: 64-81.

BORGES Ml et al. 2012. Características físico-químicas del suelo y su asociación con macroelementos en áreas destinadas a pastoreo en el estado Yaracuy. Bioagro 24: 121-126.

BROWN S. 1997. Estimating biomass and biomass change of tropical forests: a primer. Urbana: FAO Forestry Paper 134. 138p.

CHACÓN E et al. 2007. Los recursos agroalimentarios para la producción de carne y leche en los llanos venezolanos. In: I Simposio para tecnologías para la ganadería de los llanos de Venezuela. Capítulo IV. 7-45p.

DEPABLOS L et al. 2009. Nutrición mineral en sistemas ganaderos de las sabanas centrales de Venezuela. Zootecnia Tropical 27: 27-38.

DONNER E et al. 2012. Ageing of zinc in highly-weathered iron-rich soils. Plant Soil 361: 83-95.

DUNCAN A. 1974. Quality Control and Industrial Statiscs. 4.ed. Filadelfia: Irwin Homewoods III.

GODOY $S$ et al. 2007. Nutrición mineral de bovinos en las sabanas orientales de Venezuela. Cusco: APPA. 4p.

HERNÁNDEZ RM et al. 2011. La integración del conocimiento local y científico en el manejo sostenible de suelos en agroecosistemas de sabanas. Interciencia 36: 104-112.

HIDALGO-SUÁREZ AE et al. 2019. Evaluaciones físico-químicas y geoambientales para incrementar las producciones agropecuarias en la UBPC Antonio Maceo. Ciencia \& Futuro 9: 98-115.

HOLLAND JE et al. 2019. Biomass, feed quality, mineral concentration and grain yield responses to potassium fertilizer of dual-purpose crops. New Zealand Journal of Agricultural Research 62: 476-494.

JOHNSON HM et al. 2019. Influence of Land Management Strategies on Browse and Nutritional Quality of Grassland Shrub. Rangeland Ecology and Management 72: 654-660.

LIMA FP \& BASTOS RP 2019. Perceiving the invisible: Formal education affects the perception of ecosystem services 
provided by native areas. Ecosystem Services 40:10-29.

LÓPEZ MS et al. 2008. Evaluación de la nutrición mineral en sabanas bien drenadas al sur del estado Monagas, Venezuela. Revista científica 18: 197-20.

LOZANO Z et al. 2012. Disponibilidad de fósforo en un suelo de las sabanas bien drenadas venezolanas, bajo diferentes coberturas y tipos de fertilización. Interciencia 37: 820-827.

McDOWELL LR \& ARTHINGTON JD. 2005. Minerales para rumiantes en pastoreo en regiones tropicales. 4.ed. Florida: Universidad de La Florida.

MOSQUERA P \& LASCANO C. 1992. Producción de leche de vacas en pasturas de Brachiaria decumbens solo y con acceso controlado a bancos de proteína. Pasturas Tropicales 14: 2-10.

PHILP JN et al. 2019. Forage options to sustainably intensify smallholder farming systems on tropical sandy soils. A review. Agronomy for Sustainable Development 39: 25-30.

RAJKUMAR MS et al. 2012. Perspectives of plant-associated microbes in heavy metal phytoremediation. Biotechnology Advances 30: 1562-1574.

RAMÍREZ-IGLESIAS E et al. 2017a. Dinámica del fósforo en un agroecosistema conservacionista maíz-ganado de sabanas neotropicales. Revista Colombiana de Ciencia Animal-RECIA 9: 147-157.

RAMÍREZ-IGLESIAS E et al. 2017b. Relaciones suelo-planta-animal en un sistema agroecológico de siembra directa y asociación de coberturas maíz-ganado en sabanas bien drenadas de Venezuela. Relaciones. Acta Biológica Venezuelica 37: 67-87.

RAMÍREZ-IGLESIAS E et al. 2020. Consumption, digestibility and cattle condition according to forage composition and quality in maize-cattle from conservation-based agroecosystems AIMS agriculture and Food 2020 5: 480-499.

RIERA J \& GUERRERO I. 1984. Caracterización agroecológica de la región oriental de Guárico. Sub estación Experimental Valle de la Pascua: FONAIAP. 140-150p.

RODAS-GONZÁLEZ A et al. 2006. Características al sacrificio, rasgos de la canal y rendimiento ruminal, degradabilidad de materia seca y concentraciones de urea en novillos Criollo Limonero sometidos a suplementación durante la fase de ceba a pastoreo. Revista Científica 16: 315-324.

RODRÍGUEZ M et al. 2004. Recuperación de pasturas en sabanas bien drenadas del Estado Monagas. INIA 1: 60-62p.

SÁNCHEZ J \& MORENO R. 1994. Efecto del uso de Mantillos en la práctica del Intercultivo. Los sistemas de siembra con cobertura. New York: Cornell University. 201-216p.

SHAIN DH et al. 2005. Evaluation of grazing alternate summer and fall forages in extensive beef cattle production systems. The Professional Animal Scientist 21: 390-402.

SRIVASTAVA AK et al. 2020. Conceptos emergentes de la homeostasis del potasio en plantas. Revista de botánica experimental 71: 608-619.

SLANAC AL et al. 2019. Ruminal degradability of dry matter Chloris gayana hay treated with urea in cattle. Compendio de Ciencias Veterinarias 9: 18-23.

VIERA RV et al. 2019. Respuesta de vacas en producción lechera y emisión potencial de metano con relación a la altura inicial y residual del pastizal. Revista Ecuatoriana de Ciencia Animal 2: 1-6. 